\title{
REKONSILIASI DI ACEH: PELUANG DAN TANTANGANNYA
}

\author{
Muhammad Heikal Daudy \\ Fakultas Hukum, Universitas Muhammadiyah Aceh \\ Jln. Kampus Unmuha No.91, Bathoh, Kota Banda Aceh, Aceh, 23115. \\ Muhammad.heikal@unmuha.ac.id
}

\begin{abstract}
Political and armed conflict has long been over in Aceh. Various patterns of resolution of human rights violations that have been carried out have not been successful. This review in the form of scientific writing presents the concept of reconciliation in order to strengthen constructive and sustainable peace in the Serambi Mekkah. Given the importance of access to justice for conflict-affected communities, which is nothing but a form of ikhtiar to unravel the red thread of history of armed and humanitarian violence that should not be receded for a sense of justice and accountability for various alleged human rights violations in Aceh that still have a mystery. All elements of society are currently waiting for the certainty of the answer from the end of a long process, all of which began with the willingness of the government to truly solve this humanitarian problem in a fair and dignified manner. The purpose of reconciliation itself ultimately leads to the tapping of the hearts of the perpetrators to admit their historical mistakes.
\end{abstract}

Keywords: Reconciliation, Opportunities, Challenges

Intisari: Pertikaian politik dan bersenjata telah lama usai di Aceh. Berbagai pola penyelesaian pelanggaran hak asasi manusia yang pernah dilakukan belum berhasil untuk dituntaskan. Ulasan dalam bentuk tulisan ilmiah ini menyuguhkan konsep rekonsiliasi demi penguatan damai yang konstruktif dan berkesinambungan di Serambi Mekkah. Mengingat pentingnya akses keadilan bagi masyarakat korban konflik yang tak lain sebagai bentuk ikhtiar untuk mengurai benang merah sejarah kekerasan bersenjata dan kemanusiaan yang tidak boleh surut demi rasa keadilan dan pertanggungjawaban terhadap berbagai dugaan pelanggaran hak asasi manusia di Aceh yang masih menyimpan misteri. Segenap elemen masyarakat saat ini menunggu kepastian jawaban dari akhir sebuah proses panjang, yang kesemuanya itu bermula dari adanya kemauan pemerintah untuk secara sungguh-sungguh menyelesaikan persoalan kemanusiaan ini secara adil dan bermartabat. Tujuan rekonsiliasi sendiri pada akhirnya berujung kepada terketuknya pintu hati sanubari para pelaku untuk mengakui kesalahan sejarahnya.

Kata Kunci: Rekonsiliasi, Peluang, Tantangan.

\section{Pendahuluan}

Sejarah panjang kekerasan politik dan bersenjata di Aceh merupakan tragedi kemanusiaan yang paling lama berlangsung di Indonesia. Penyelesaian masalah Aceh mencapai titik temu dibawah duet kepemimpinan Susilo Bambang Yudhoyono dan Jusuf Kalla sebagai Presiden dan Wakil Presiden periode 2004-2009, yang memutuskan melakukan perundingan damai dengan pihak Gerakan Aceh Merdeka (GAM) yang difasilitasi oleh Crisis Management Initiative (CMI) di Helsinki, Finlandia, melalui penandatanganan Memorandum Of Understanding (MoU) tanggal 15 Agustus 2005. 
Pada Agustus 2018 mendatang MoU Helsinki akan genap berusia 13 (tiga belas) tahun. Banyak kemajuan telah dirasakan oleh masyarakat Aceh, ini tidak terlepas dari komitmen kuat yang dibangun Pemerintah Republik Indonesia dan GAM untuk terus membangun kepercayaan (truth building) demi terciptanya perdamaian abadi di Aceh. Setidaknya demikian suasana yang terekam selama ini. Sejumlah program terus digulirkan dan dilaksanakan dalam rangka mengejar ketertinggalan Aceh dari daerahdaerah lain.

Perkembangan Aceh dalam aspek pembangunan pasca MoU Helsinki berkembang dengan pesat. Hal ini terwujud akibat adanya rekonsiliasi yang terpadu antara pemerintah pusat dengan Aceh dalam mewujudkan pembangunan. Dasar syariat Islam yang menggema juga mempengaruhi pola pembangunan di Aceh. Syariat Islam berbasis adat lokal yang dikembangkan dan dilaksanakan oleh lembaga khusus yang dibentuk di Aceh berdasarkan amanah MoU Helsinki itu sendiri.

Selain pembangunan infra struktur, Aceh juga berinisiatif untuk melanjutkan pemenuhan Hak Asasi Manusia berlandaskan Undang-Undang No. 11 Tahun 2006 tentang Pemerintahan Aceh. Pemenuhan tersebut difokuskan dalam penanganan korban konflik yang terjadi di Aceh dengan membentuk sebuah lembaga yaitu Komisi Kebenaran dan Rekonsiliasi Aceh (KKR Aceh). ${ }^{1}$ Lembaga ini dikuatkan legalitasnya dalam Pasal 229 Undang-Undang No. 11 Tahun 2006, yang berbunyi:

(1) Untuk mencari kebenaran dan rekonsiliasi, dengan Undang-Undang ini dibentuk Komisi Kebenaran dan Rekonsiliasi di Aceh.

(2) Komisi Kebenaran dan Rekonsiliasi di Aceh sebagaimana dimaksud pada ayat (1) merupakan bagian tidak terpisahkan dengan Komisi Kebenaran dan Rekonsiliasi.

(3) Komisi Kebenaran dan Rekonsiliasi di Aceh bekerja berdasarkan peraturan perundang-undangan.

(4) Dalam menyelesaikan kasus pelangggaran hak asasi manusia di Aceh, Komisi Kebenaran dan Rekonsiliasi di Aceh dapat mempertimbangkan prinsip-prinsip adat yang hidup dalam masyarakat.

Kelahiran KKR Aceh dipicu oleh beberapa sebab, antara lain: Pertama, untuk keberlanjutan perdamaian di Aceh dalam rangka pemenuhan hak hak-hak korban atas kebenaran, keadilan, dan hak untuk mendapatkan reparasi; Kedua, meluruskan sejarah demi pembelajaran bangsa agar kejadian serupa tidak terulang lagi di masa mendatang, dan; Ketiga, membentuk budaya menghargai hak asasi manusia (HAM) ${ }^{2}$

Artikel ini ingin menawarkan pola rekonsiliasi yang diharapkan dapat memberi solusi dalam penyelesaian pelanggaran hak asasi yang sudah berlangsung lama.

\footnotetext{
1 Zaki Ulya, Politik Hukum Pembentukan Komisi Kebenaran Dan Rekonsiliasi Aceh: ReFormulasi Legalitas KKR Aceh, Jurnal Petita, Vol. 2 No. 2, 2017, hlm. 137

${ }^{2}$ Ibid., hlm. 138. Juga dapat dilihat dalam Pricilla B. Hayner, Kebenaran Tak Terbahasakan Refleksi Pengalaman Komisi-Komisi Kebenaran, Kenyataan dan Harapan, (Jakarta: ELSAM, 2005), hlm. 3
} 


\section{Metode Penelitian}

Kajian ini tidak hanya menggunakan pendekatan aspek peraturan perundangundangan (yuridis approach). Melainkan berusaha mengombinasikan sejumlah pendekatan aspek non-hukum lainnya (non-yuridis approach) seperti filsafat dan sejarah, dengan tidak melupakan hubungan berbagai sub-sistem dalam penyelesaikan pelanggaran hak asasi manusia pada umumnya, dan kajian ini dilakukan secara kualitatif.

\section{Hasil Penelitian dan Pembahasan}

\section{Aspek Historis, Filosofis dan Sosiologis}

Aceh merupakan daerah yang mengalami penderitaan hebat, karena pelanggaran hak asasi manusia yang tergolong berat (gross violation of human rights) akibat konflik berkepanjangan. Berbagai peristiwa kekerasan yang tergolong masif, pernah terjadi pada masa Daerah Operasi Militer (DOM) diterapkan di Aceh beserta berbagai operasi militer sesudahnya. ${ }^{3}$

Melalui sejumlah advokasi yang dilakukan beberapa lembaga hak asasi manusia, baik formal (lembaga negara) maupun informal (Lembaga Swadaya Masyarakat) sebutsaja Komnas HAM, Kontras, dan YLBHI, menyebutkan sejumlah kasus penting di Aceh yakni kasus Rumah Geudong, kuburan massal Bukit Tengkorak, kasus Gedung KNPI (pasca DOM) sudah diproses Mahkamah Militer, kasus Idi Cut, kasus Simpang KKA, kasus Tgk. Bantaqiah (terakhir disebut diproses melalui pengadilan koneksitas), kasus relawan RATA, kasus Bumi Flora, dan sejumlah kasus yang terjadi pada masa Darurat Militer dan Darurat Sipil.

Pelanggaran hak asasi manusia yang pernah terjadi di Aceh bukan hanya isapan jempol belaka seperti dikemukakan oleh pengamat, melainkan memperoleh pengakuan dari pemerintah dan aparat keamanan yang pernah bertugas dalam berbagai operasi di Aceh. Sampai saat ini, kasus-kasus pelanggaran HAM di Aceh belum diadili seluruhnya, dengan berbagai alasan normatif bahkan politis. ${ }^{4}$

Contoh peristiwa di atas, tidak hanya telah melukai hati rakyat Aceh secara fisik, tetapi juga harkat, martabat, harga diri dan keyakinannya. Memori kolektif masyarakat Aceh, khususnya masyarakat yang menjadi korban dari berbagai peristiwa pada masa konflik, sangat tidak mungkin melupakan itu semua, terkecuali karena masyarakat Aceh saat ini sudah tertidur lelap, karena lalai berasyik-masyuk menikmati damai yang terkesan nyaman, namun belum menyentuh hakikat "perdamaian" sebagaimana harapan seluruh lapisan masyarakat di Aceh.

Oleh karena menimbang berbagai hambatan yang mungkin dialami banyak pihak selama ini di Aceh. Terlepas dari berbagai perbedaan pandangan para pakar dan aktivis yang senantiasa memperjuangkan konsep ideal terhadap penyelesaian pelanggaran hak asasi manusia di Aceh. Penulis dalam banyak kesempatan sangat optimis bahwa peluang

${ }^{3}$ Zaki Ulya, Refleksi Memorandum of Understanding (MoU) Helsinki dalam Kaitan Makna Otonomi Khusus Di Aceh, Jurnal Konstitusi, Vol. 11 No. 2, 2014, hal. 372

4 Iskandar A. Gani, Pendekatan Yudisial Penyelesaian Kasus Pelanggaran Hak Asasi Manusia di Aceh, Unsyiah Press, Darussalam, 2007, hlm. 6. 
penyelesaian "dosa-dosa masa lalu" tersebut, akan berhasil melalui konsep tunggal yaitu "never to forget but to forgive" dengan arti kata lain "tidak melupakan, tetapi memaafkan" melalui pengungkapan kebenaran yang dilakukan oleh sebuah komisi yang bekerja dan didesain untuk tujuan tersebut.

Sejarah mencatat beberapa cerita sukses (success story) negara-negara yang telah berhasil mengurai benang kusut masa lalunya melalui pendekatan KKR. Maka Indonesia seperti di Aceh sangat patut untuk mempertimbangkan alternatif solusi ini, sebagaimana mandat Pasal 229 ayat (1) UU Nomor 11 Tahun 2006 tentang Pemerintahan Aceh. ${ }^{5}$

Muhammad Siddiq Armia dalam tulisannya menyebutkan bahwa Nota Kesepahaman (MoU) di Helsinki pada tahun 2005, yang mana Pemerintah Aceh setuju untuk menerima tanpa syarat Undang-Undang tentang Pemerintah Aceh, memberikan prinsip-prinsip otonomi khusus dan mengakhiri konflik 30 tahun. Undang-undang memerintahkan secara eksplisit dan implisit untuk membuat undang-undang tertentu untuk menerapkan norma-norma otonomi. Meskipun disahkan oleh peraturan, baik Pemerintah Aceh dan Pemerintah Pusat telah terlibat dalam konflik peraturan yang tak berkesudahan, termasuk peraturan perundang-undangan pertanahan dan bendera. ${ }^{6}$

Bagi masyarakat Aceh prosesi memaafkan adalah sebaik-baiknya perbuatan dan sebagai salah satu tanda ketaqwaan kepada Allah SWT. Sangat penting untuk memulihkan harkat, martabat dan harga diri mereka sebagai rakyat yang bebas, dimana dengan begitu mereka dapat menjalankan kewajiban sebagai bagian anak bangsa dalam Negara Kesatuan Republik Indonesia (NKRI) yang merdeka, damai, dan adil. Terlebih lagi masyarakat Aceh menjadikan Islam sebagai pandangan hidup, sehingga proses penciptaan perdamaian merupakan suatu yang dianjurkan, karena Islam melarang menebarkan suatu kebencian dan peperangan atau dendam.

Oleh karena itu usaha "rekonsiliasi" sangat dibenarkan dengan klausul yang jelas atas dasar pertimbangan kepentingan yang sama. Klausul yang jelas itu tentunya bertujuan untuk mencapai kedamaian dan saling menghormati, tanpa merugikan salah satu pihak, apalagi yang dirugikan itu adalah pihak yang lemah.

Untuk itu bila ada suatu perdamaian tetapi merugikan pihak yang lemah, maka seorang pemimpin atau penguasa (negara) dalam hal ini, wajib menolak klausul perdamaian atau rekonsiliasi tersebut. Hal ini sesuai dengan fitrah manusia yang telah menggariskan bahwa, pihak yang lemah harus dilindungi serta mendapat jaminan kehidupan yang layak. Sehingga jika ia dirugikan akibat klausul perdamaian yang tidak berimbang, maka hasilnya pun mudah untuk ditebak karena akan berujung kepada tidak tercapainya keadilan sebagaimana diharapkan.

\footnotetext{
${ }^{5}$ Muhammad Heikal Daudy, Jalan Panjang Menuju Rekonsiliasi, Jurnal Kanun, FH UNSYIAH, Volume 183, 2016, hlm. 380.

${ }^{6}$ Muhammad Siddiq Armia, Autonomy in Aceh-Indonesia, from Armed Conflict to Regulation Conflict, Proceedings of The 7th Annual International Conference (AIC) Syiah Kuala University and The 6th International Conference on Multidisciplinary Research (ICMR) in conjunction with the International Conference on Electrical Engineering and Informatics (ICELTICs) 2017, October 18-20, 2017, Banda Aceh, Indonesia, hlm. 796
} 


\section{Aspek Politis dan Yuridis}

Tuntutan masyarakat Aceh terhadap penyelesaian pelanggaran hak asasi manusia yang tergolong 'berat' memang bukan pekerjaan ringan. Pemerintahan Indonesia pasca reformasi, dihadapkan pada situasi yang sangat dilematis untuk mengupayakan keberhasilannya menjawab tuntutan masyarakat terkait penyelesaian pelanggaran HAM masa lalu. Situasi yang sama pernah dialami sejumlah negara yang mempraktekkan corak otoritarian dalam menjalankan sistem pemerintahannya. Tak terkecuali di Aceh, sejak Desember 2006 melaksanakan model pemerintahan sendiri (self government) yang tergolong unik dalam bingkai Negara Kesatuan Republik Indonesia yang pada akhirnya, pemerintahan di masa 'peralihan' ini dengan sekuat tenaga dan segenap sumber daya yang dimiliki menginginkan agar penyelesaian kejahatan kemanusiaan yang dialaminya ditempuh dengan cara-cara damai. Selain daripada itu, terdapat dugaan banyak pihak yang menilai bahwa usaha-usaha tersebut dipandang sebagai cara penyelesaian tidak populer sebatas upaya memberi 'keadilan sementara waktu' yang jauh dari model penyelesaian permanen yang mampu memenuhi rasa adil para korban. Pertimbangannya bisa beragam, dan yang tergolong menarik adalah asumsi bahwa pola-pola penyelesaian yang mengedepankan hukum an-sich (legalistik) dapat dipastikan akan mengalami banyak hambatan dan jalan terjal yang tak berkesudahan.

Lain halnya dengan pemikiran yang menyatakan bahwa mekanisme penyelesaian pelanggaran HAM di negara ini, dinilai masih kentara dengan produk-produk hukum peninggalan rezim otoritarian yang secara otomatis akan mengundang resistensi dari banyak pihak, khususnya para korban yang terus menuntut kepastian hukum dari kekerasan yang dialaminya. Persepsi ini terbangun karena potret penegakan hukum dinegara kita pasca reformasi pun dinilai masih jauh dari harapan masyarakat. Struktur hukum positif yang saat ini berjalan belum memadai secara administratif maupun substantif. Sehingga semangat pembaharuan hukum (legal reform) menjadi sebuah keniscayaan untuk segera dilaksanakan baik dari segi konsep maupun implementasinya demi memenuhi tujuan hukum itu sendiri.

Sehubungan dengan itu, menjadi wajar jika sebahagian kalangan menyatakan bahwa KKR pun sedianya menjadi salah satu instrumen pembaharuan hukum tersebut. Mengingat keberadaannya sebagai 'model eksperimental' dari kondisi kekinian masamasa transisi yang sedang terus berlangsung. Namun persoalannya kembali tertumpu pada itikad baik dari penyelenggara negara untuk benar-benar menuntaskan pelanggaran HAM berat dengan instrumen yuridis yang ada.

Zalaquett (1989) dalam sebuah makalah yang diterbitkan The Aspen Institute (State Crime: Punishment or Pardon), menyebutkan "Dalam situasi transisi, pemerintah seringkali tidak memiliki kekuatan dalam melaksanakan banyak kewajiban positif. Haruskah pemerintah berusaha melaksanakan kewajiban itu dengan menanggung risiko ditumbangkan oleh pihak-pihak yang tanggungjawabnya sedang diselidiki?" tulisnya. ${ }^{7}$

Sejauh ini, Komisi Kebenaran dan Rekonsiliasi sebagaimana dicontohkan diberbagai belahan dunia dipertautkan oleh empat elemen umum yang harus dimiliki antara lain: Pertama, penyelidikan yang dilakukan terfokus kepada bentuk-bentuk dugaan

\footnotetext{
${ }^{7}$ Zalaquett, State Crime: Punishment or Pardon (The Aspen Institute 1989) no.pages.
} 
pelanggaran yang terjadi dimasa lalu. Kedua, Keberadaan komisi ini bertujuan untuk memperoleh segala informasi yang dibutuhkan terkait dugaan pelanggaran HAM dan kejahatan kemanusiaan lainnya selama periodeisasi tertentu yang dibatasi, dan dapat dilakukan untuk beberapa kasus sepanjang memiliki keterkaitan satu dengan yang lainnya. Ketiga, berbentuk ad-hoc dan situasional berdasarkan waktu yang telah ditentukan, menimbang masa kerja dan pengabdian profesionalnya sangat terbatas, lazimnya berakhir usai penyampaian laporan investigasi. Keempat, diberikan otoritas yang luas dalam hal aksessibilitas komisi ke lembaga/institusi manapun, dan dilegkapi instrumen hukum berupa standar operasional prosedur terhadap perlindungan para saksi. ${ }^{8}$

Haris Azhar dalam tulisannya menyebutkan bahwa dalam Undang-Undang No. 10 Tahun 2004 tentang Pembentukan Peraturan Perundang-undangan yang kemudian diubah dengan Undang-Undang No. 12 Tahun 2011, yang disebutkan aturan perundangundangan salah satunya adalah Peraturan Daerah. Salah satu prinsip yang harus dipegang teguh dalam penyusunan peraturan peraturan perundang-undangan, termasuk Perda, diantaranya soal kemanusiaan, keadilan, kepastian hukum. Hal ini menandakan bahwa Perda pun bisa dijadikan sebagai kepanjangan tangan penjaminan hak-hak asasi manusia yang dinyatakan dalam UUD 1945 dan Undang-Undang No. 11 Tahun 2006. ${ }^{9}$

Mengutip pendapat Aryos Nivada bahwa Undang-Undang No. 11 Tahun 2006 mengamanatkan dan menegaskan pembentukan KKR di Aceh, sebagaimana disebutkan dalam Pasal 229 Undang-Undang No. 11 Tahun 2006. Sedangkan teknis pelaksanaan KKR Aceh diatur dengan Qanun Aceh sebagaimana disebutkan pada Pasal 230 UndangUndang No. 11 Tahun 2006. Artinya, pemerintah pusat mau tidak mau harus mengakomodir pembentukan KKR Aceh. Aryos juga menjelaskan, meski payung hukum nasional yaitu UU No. 27 Tahun 2004 tentang KKR telah dibatalkan MK. Akan tetapi Aceh masih tetap dapat mengacu kepada 3 (tiga) instrumen hukum nasional. Instrumen hukum yang dapat digunakan yaitu TAP MPR N0 IV/1999, TAP MPR No.V/2000 dan UU Pengadilan HAM. ${ }^{10}$

Bagi Bangsa Indonesia, Komisi Kebenaran dan Rekonsiliasi telah diperkenalkan dan diakomodasi sejak Undang-Undang Nomor 26 Tahun 2000 tentang Pengadilan HAM diterbitkan. Secara kelembagaan, keberadaannya berdampingan dengan Pengadilan HAM, bahkan telah diatur tersendiri dan lebih spesifik melalui Undang-Undang Nomor 27 Tahun 2004 tentang KKR, sebelum dibatalkan oleh Mahkamah Konstitusi berdasarkan Putusan MK RI Nomor Perkara 006/PUU-IV/2006.

\footnotetext{
${ }^{8}$ Samsidar, Tarik Ulur KKR Aceh: Pengungkapan Kebenaran dan Pemenuhan Keadilan di Antara Dikotomi Hitam Putih dan di Atas Fondasi Impunitas, Dibawakan pada Seminar dan Peluncuran Hasil Penelitian : Kebenaran dan Perdamaian di Aceh "Upaya Pemenuhan Hak dan Pertanggungjawaban”, Kerja sama PUSHAM Unsyiah Kuala, KPK-Aceh dan ICTJ, Hotel Permes Palace, Banda Aceh. 2007, hlm. 1-2

${ }^{9}$ Haris Azhar, Kepala Divisi Pemantauan Impunitas dan Reformasi Institusi KontraS, Anggota Tim Perumus Konsep Komisi Kebenaran dan Rekonsiliasi Aceh Versi Masyarakat Sipil, "Prospek Hukum Komisi Kebenaran \& Ronsiliasi Aceh", http://www.kontras.org/index.php?hal=opini\&id=17, diakses pada tanggal 17 Mei 2019

10 Aryos Nivada, "Wacana pembubaran Komisi Kebenaran dan Rekonsiliasi Aceh dikecam", http://www.hetanews.com/article/91808/wacana-pembubaran-komisi-kebenaran-danrekonsiliasiaceh-dikecam, diakses pada tanggal 17 Mei 2019
} 
Bagi Bangsa Indonesia, Komisi Kebenaran dan Rekonsiliasi telah diperkenalkan dan diakomodasi sejak Undang-Undang Nomor 26 Tahun 2000 tentang Pengadilan HAM diterbitkan. Secara kelembagaan, keberadaannya berdampingan dengan Pengadilan HAM, bahkan telah diatur tersendiri dan lebih spesifik melalui Undang-Undang Nomor 27 Tahun 2004 tentang KKR, sebelum dibatalkan oleh Mahkamah Konstitusi berdasarkan Putusan MK RI Nomor Perkara 006/PUU-IV/2006.

Optimisme dari seluruh komponen bangsa harus tercermin dari dukungannya kelak terhadap keberhasilan kerja-kerja KKR, meski dengan risiko yang tidak mudah, serta menimbang yurisdiksi yang juga terbatas (KKR Aceh). Meskipun pada tataran lokal, masyarakat Aceh optimis bahwa sumbangsihnya (legacy) melalui proses pengungkapan kebenaran dan rekonsiliasi tersebut menjadi modal yang sangat berharga bagi sejarah. Dan sudah menjadi kesepakatan bersama selaku anak bangsa, bahwa jangan sampai masyarakat Aceh kembali hanyut dalam kubang darah akibat goresan luka kekerasan yang memilukan.

Berbagai pertimbangan dan alasan sebagaimana telah dikemukakan di atas, praktis memosisikan Peraturan Daerah (Qanun) Aceh Nomor 17 Tahun 2013 tentang Komisi Kebenaran dan Rekonsiliasi Aceh, sangat strategis dan perlu mendapat dukungan penuh dari pemerintah (pusat dan daerah). Oleh karena qanun ini merupakan solusi alternatif dari tantangan sejarah kekerasan panjang di masa lalu yang pernah terjadi. Sekaligus menjawab kebuntuan hukum yang selama ini berusaha "melawan lupa" atas segala persoalan kemanusiaan yang sepatutnya mendapat perhatian semua pihak khususnya negara (state responcibility) sejak awal.

Salah satu tugas penting yang diberikan Qanun kepada KKR Aceh adalah melakukan penyelidikan dan mengumpulkan informasi dalam rangka pengungkapan kebenaran, reparasi dan rekonsiliasi. Tugas ini menjadi dasar pemberian rekomendasi KKR Aceh kepada pemerintah. Dalam konteks ini, Qanun KKR Aceh memberikan wewenang pada KKR Aceh untuk memastikan pemerintah melaksanakan seluruh rekomendasinya. Wewenang ini penting untuk menjaga upaya pengungkapan kebenaran dan rekonsiliasi tetap berjalan pada arah yang tepat. ${ }^{11}$

Terpenting bahwa Qanun Aceh tentang KKR, turut membuka peluang untuk mewujudkan rekonsiliasi secara nasional. Pengalaman KKR Aceh dapat menjadi rule of model bagi penyelesaian kasus-kasus serupa nantinya. Oleh karena permasalahan yang dihadapi masyarakat Aceh pada masa transisi ini, menstimulasi segenap energi bangsa untuk berfikir secara holistik dan futuristik, dimana setiap permasalahan yang dihadapi harus dicarikan solusi bijak bukan malah menunda-nunda untuk diselesaikan.

\section{Penutup}

Tuntutan masyarakat terhadap penyelesaian pelanggaran hak asasi manusia memang bukan pekerjaan mudah. Pemerintah Indonesia pasca-reformasi, menghadapi masalah pelik. Keadaan ini turut berlaku dibelahan dunia lain, bahkan menjangkiti elite

11 Abraham Utama, Jalan Terjal Pengesahan Qanun KKR Aceh, Opini, Koleksi Pusat Dokumentasi ELSAM, tt, hlm. 4 
Aceh di tingkat lokal. Pada akhirnya, pemerintahan di masa transisi cenderung berusaha menyelesaikan kejahatan hak asasi manusia yang tergolong berat, dengan berupaya mendamaikan, tidak dapat dipungkiri tatkala usaha-usaha tersebut dinilai sebagai bentuk 'keadilan temporer', yang dipastikan sulit memenuhi rasa adil para korban secara ideal. Pertimbangannya bisa beragam, salah satu yang paling menarik adalah asumsi bahwa pendekatan hukum semata diyakini tidak akan berhasil.

\section{Daftar Pustaka}

\section{A. Buku dan Jurnal}

Abraham Utama, Jalan Terjal Pengesahan Qanun KKR Aceh, Opini, Koleksi Pusat Dokumentasi ELSAM, tt.

Iskandar A. Gani, Pendekatan Yudisial Penyelesaian Kasus Pelanggaran Hak Asasi Manusia di Aceh, Unsyiah Press, Darussalam, 2007.

Muhammad Heikal Daudy, Jalan Panjang Menuju Rekonsiliasi, Jurnal Kanun, FH UNSYIAH, Volume 183, 2016.

Muhammad Siddiq Armia, Autonomy in Aceh-Indonesia, from Armed Conflict to Regulation Conflict, Proceedings of The 7th Annual International Conference (AIC) Syiah Kuala University and The 6th International Conference on Multidisciplinary Research (ICMR) in conjunction with the International Conference on Electrical Engineering and Informatics (ICELTICs) 2017, October 18-20, 2017, Banda Aceh, Indonesia

Pricilla B. Hayner, Kebenaran Tak Terbahasakan Refleksi Pengalaman Komisi-Komisi Kebenaran, Kenyataan dan Harapan, ELSAM, Jakarta, 2005

Samsidar, Tarik Ulur KKR Aceh: Pengungkapan Kebenaran dan Pemenuhan Keadilan di Antara Dikotomi Hitam Putih dan di Atas Fondasi Impunitas, Dibawakan pada Seminar dan Peluncuran Hasil Penelitian : Kebenaran dan Perdamaian di Aceh "Upaya Pemenuhan Hak dan Pertanggungjawaban", Kerja sama PUSHAM Unsyiah Kuala, KPK-Aceh dan ICTJ, Hotel Permes Palace, Banda Aceh. 2007

Zaki Ulya, Refleksi Memorandum of Understanding (MoU) Helsinki dalam Kaitan Makna Otonomi Khusus Di Aceh, Jurnal Konstitusi, Vol. 11 No. 2, 2014

Politik Hukum Pembentukan Komisi Kebenaran Dan Rekonsiliasi Aceh: ReFormulasi Legalitas KKR Aceh, Jurnal Petita, Vol. 2 No. 2, 2017

Zalaquett, State Crime: Punishment or Pardon, The Aspen Institute, 1989.

\section{B. Peraturan Perundang-Undangan}

Undang-Undang Nomor 26 Tahun 2000 tentang Pengadilan Hak Asasi Manusia (Lembaran Negara Republik Indonesia Tahun 2000 Nomor 208, Tambahan

Lembaran Negara Republik Indonesia Nomor 4026) 
Undang-Undang Nomor 27 Tahun 2004 tentang Komisi Kebenaran dan Rekonsiliasi (Lembaran Negara Republik Indonesia Tahun 2004 Nomor 114, Tambahan Lembaran Negara Republik Indonesia Nomor 4429)

Undang-Undang Nomor 11 Tahun 2006 tentang Pemerintahan Aceh (Lembaran Negara Republik Indonesia Tahun 2006 Nomor 62, Tambahan Lembaran Negara Republik Indonesia Nomor 4633)

Qanun Nomor 17 Tahun 2013 Tentang Komisi Kebenaran dan Rekonsiliasi Aceh (Lembaran Aceh Tahun 2013 Nomor 1)

Putusan Mahkamah Konstitusi Nomor Perkara 006/PUU-IV/2006 Tentang Komisi Kebenaran dan Rekonsiliasi Terhadap Undang-Undang Dasar 1945.

\section{Internet}

Aryos Nivada, "Wacana pembubaran Komisi Kebenaran dan Rekonsiliasi Aceh dikecam", http://www.hetanews.com/article/91808/wacana-pembubaran-komisikebenaran-dan-rekonsiliasiaceh-dikecam, diakses pada tanggal 17 Mei 2019

Haris Azhar, Kepala Divisi Pemantauan Impunitas dan Reformasi Institusi KontraS, Anggota Tim Perumus Konsep Komisi Kebenaran dan Rekonsiliasi Aceh Versi Masyarakat Sipil, "Prospek Hukum Komisi Kebenaran \& Rekonsiliasi Aceh", http://www.kontras.org/index.php?hal=opini\&id=17, diakses pada tanggal 17 Mei 2019 